Review

\title{
Alphavirus-Based Vaccines
}

\section{Kenneth Lundstrom}

PanTherapeutics, Rue des Remparts 4, CH1095 Lutry, Switzerland;

E-Mail: lundstromkenneth@gmail.com; Tel.: +41-79-776-6351

Received: 2 April 2014; in revised form: 3 June 2014 / Accepted: 4 June 2014 /

Published: 16 June 2014

\begin{abstract}
Alphavirus vectors have demonstrated high levels of transient heterologous gene expression both in vitro and in vivo and, therefore, possess attractive features for vaccine development. The most commonly used delivery vectors are based on three single-stranded encapsulated alphaviruses, namely Semliki Forest virus, Sindbis virus and Venezuelan equine encephalitis virus. Alphavirus vectors have been applied as replication-deficient recombinant viral particles and, more recently, as replication-proficient particles. Moreover, in vitro transcribed RNA, as well as layered DNA vectors have been applied for immunization. A large number of highly immunogenic viral structural proteins expressed from alphavirus vectors have elicited strong neutralizing antibody responses in multispecies animal models. Furthermore, immunization studies have demonstrated robust protection against challenges with lethal doses of virus in rodents and primates. Similarly, vaccination with alphavirus vectors expressing tumor antigens resulted in prophylactic protection against challenges with tumor-inducing cancerous cells. As certain alphaviruses, such as Chikungunya virus, have been associated with epidemics in animals and humans, attention has also been paid to the development of vaccines against alphaviruses themselves. Recent progress in alphavirus vector development and vaccine technology has allowed conducting clinical trials in humans.
\end{abstract}

Keywords: alphaviruses; vaccines; naked RNA; DNA vaccines; recombinant particles; protection against lethal virus challenges; tumor protection; clinical trials 


\section{Introduction}

Alphaviruses are single-stranded RNA viruses with an envelope structure belonging to the family of Togaviridae [1]. Certain alphaviruses have been associated with pathogenicity, resulting in global fever epidemics, such as observed recently for Chikungunya virus [2]. Furthermore, Semliki Forest virus (SFV) [3] and Venezuelan equine encephalitis (VEE) virus [4] have been identified as the causes of an outbreak of febrile illness in Central Africa and an epidemic in horses and humans in South America, respectively. Despite this potential concern, several alphaviruses, including SFV [5], Sindbis virus (SIN) [6] and VEE [7] have been subjected to the engineering of vectors for heterologous gene expression. In these cases, attenuated strains have been employed.

Several types of vector systems have been engineered. There are three types of replication-deficient vectors consisting of naked RNA, recombinant particles and layered DNA vectors (Figure 1). The application of naked RNA vectors involves the use of in vitro transcribed RNA from an expression vector consisting of the viral nonstructural replicase genes and the foreign gene of interest downstream of the strong subgenomic promoter. The production of recombinant particles requires the co-transfection of in vitro transcribed RNA from an expression vector (as described above) and a helper vector supplying the viral structural genes into mammalian cell lines (for example, baby hamster kidney (BHK) cells). The generated particles are capable of one round of infection of a broad range of host cells, but due to the selective packaging of only expression vector RNA, no further virus production occurs. The layered DNA vector system consists of delivery of a DNA vector providing foreign gene expression from a CMV promoter. Furthermore, the engineering of vectors with an additional subgenomic promoter to the full-length genome allows for the generation of replication-proficient particles, which can provide improved delivery and extended gene expression. All alphavirus vectors described take advantage of the extremely efficient RNA replication, resulting in some 200,000 RNA copies from each RNA molecule. The essential question is: which vector system to use? Obviously, replication-proficient particles can provide efficient delivery, but suffer from potential insufficiency related to safety aspects. Although replication-deficient particles provide a higher level of safety, there is still a marginal risk of the generation of replication-proficient particles through non-homologous recombination. To minimize any unwanted recombination events, a split helper vector system with capsid and envelope genes expressed from separate helper vectors has been engineered [8].

So far, alphaviruses have been applied for the expression of a number of topologically different recombinant proteins [9]. Particularly, the use of SFV particles has resulted in high expression levels of integral membrane proteins in various mammalian host cell lines [10], in primary neurons [11] and in vivo [12]. For vaccine development, vectors based on SFV, SIN and VEE have been applied as naked RNA, recombinant virus particles and layered DNA vectors [13]. In this context, viral and tumor antigens have been administered in various animal models to elicit neutralizing antibodies and protection against challenges with tumor cells or lethal doses of viruses. Moreover, non-viral pathogens have been subjected to vaccine development. Replicon particles derived from VEE have furthermore demonstrated activity as safe and potent systemic, mucosal and cellular adjuvants when co-administered with antigen [14]. Finally, as alphaviruses have been identified as the cause of viral epidemics in animals and humans, a number of approaches have been initiated for immunization 
against alphavirus-based infections. In this review, the latest development on alphavirus vectors for vaccine production is summarized.

Figure 1. Alphavirus vector systems for vaccine delivery. (A) Naked RNA vector in vitro transcribed from plasmid DNA. (B) Replication-deficient alphavirus particles generated in baby hamster kidney (BHK) cells after co-transfection of in vitro transcribed RNA from the expression and helper vectors. (C) Layered DNA vector for plasmid immunization. SP6, polymerase promoter; 26S, subgenomic alphavirus promoter; CMV, cytomegalovirus promoter; polyA tail, polyadenylation signal.

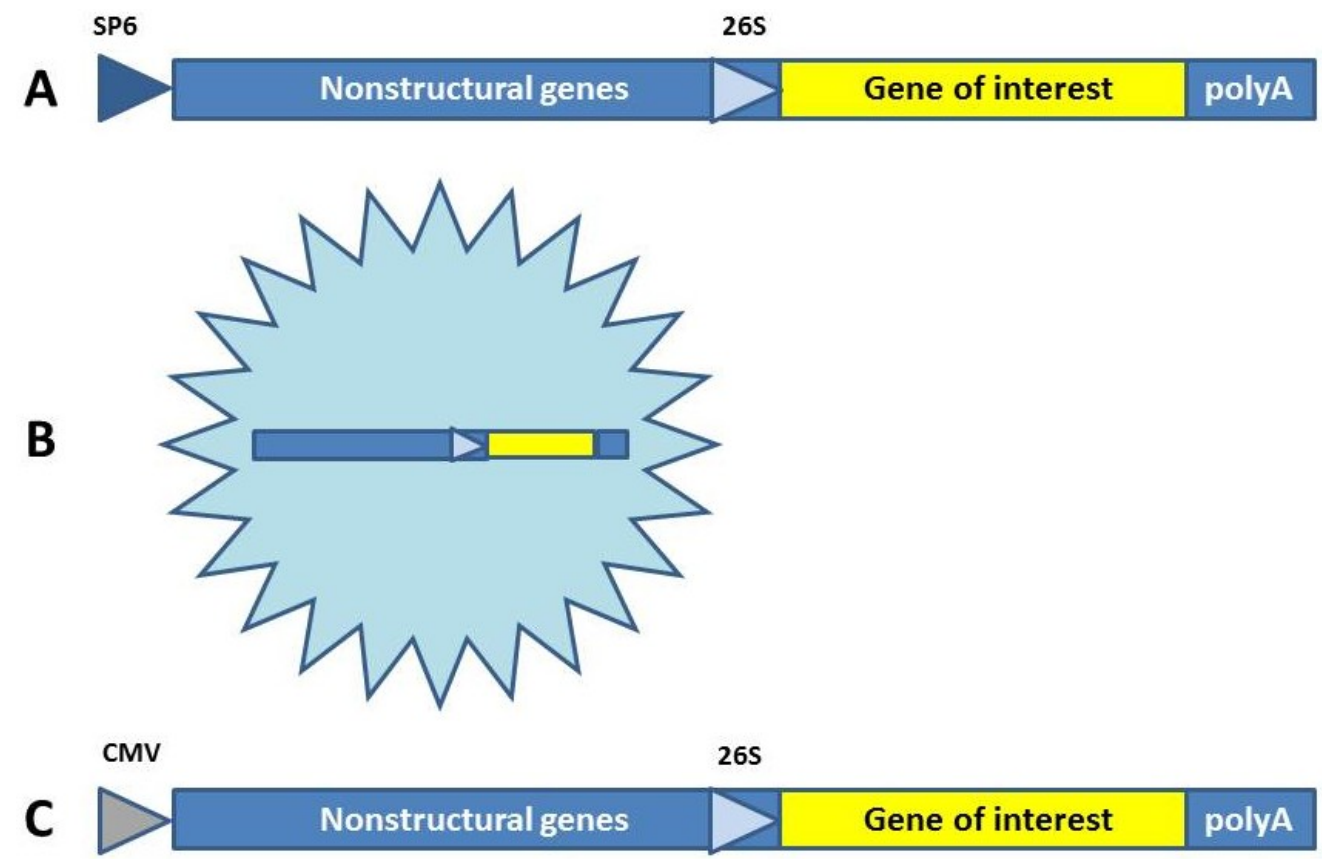

\section{Viral Vaccine Approaches}

Due to their immunogenic properties, viral structural proteins have been popular targets for alphavirus-based vaccine development [13] (Table 1). In this context, immunization with SFV particles expressing influenza nucleoprotein (NP) elicited a strong immune response in mice [15]. Moreover, VEE-based expression of influenza hemagglutinin (HA) provided protection against challenges with H5N1 virus in chicken [16]. Similarly, SFV particles expressing the HIV envelope [17] and gp41 [18] and VEE particles expressing HIV MA/CA [19] showed humoral and CTL (cytotoxic T-lymphocyte) responses in mice. Furthermore, a VEE particle vaccine expressing the cluster IV H3N2 swine influenza HA gene demonstrated protection against challenges with homologous influenza virus [20]. Likewise, mice and guinea pigs vaccinated with VEE particles expressing Ebola NP [21] and GP [22], respectively, provided protection against challenges with lethal doses of Ebola virus. 
Table 1. Alphavirus-based vaccine development for viral targets.

\begin{tabular}{|c|c|c|c|c|c|}
\hline Virus & Target & Vector/Delivery & Immunization & Response & Reference \\
\hline \multirow[t]{2}{*}{ BVDV } & E2 & VEE/Particles & Calf & BVDV protection & {$[23]$} \\
\hline & NS3 (p80) & SFV/DNA & Mouse & CTL, CMI & [24] \\
\hline $\mathrm{CMV}$ & $\mathrm{gB} / \mathrm{pp} 65-1 \mathrm{E} 1$ & VEE/Particles & Human Phase I & Neutralizing Abs & {$[25]$} \\
\hline CSFV & $\mathrm{E} 2$ & SFV/DNA & Swine & CSFV protection & {$[26]$} \\
\hline Dengue & PrME, E85 & VEE/Particles & Macaque & Dengue protection & [27] \\
\hline \multirow[t]{3}{*}{ Ebola } & NP & VEE/Particles & Mouse & Ebola protection & {$[21]$} \\
\hline & NP, GP & VEE/Particles & Guinea pig & Ebola protection & {$[22]$} \\
\hline & VP24, 30, 35, 30 & VEE/Particles & Mouse & Ebola protection & {$[28]$} \\
\hline \multirow[t]{2}{*}{ Hepatitis B } & $\mathrm{cAg}$ & SIN/DNA & Mouse & Specific Abs & [29] \\
\hline & sAg & SIN/DNA & Mouse & Specific Abs & [29] \\
\hline \multirow[t]{3}{*}{ Hepatitis C } & $\mathrm{cAg}$ & SFV/Particles, DNA & Mouse & CTL & {$[30]$} \\
\hline & NS3 & SFV/Particles & Mouse & Cellular & {$[31]$} \\
\hline & nsPs & SFV/Particles & Mouse & $\mathrm{CD}^{+} \mathrm{T}$-cell response & [32] \\
\hline $\mathrm{HeV}$ & Glycoprotein & VEE/Particles & Mouse & Neutralizing Abs & {$[33]$} \\
\hline \multirow[t]{3}{*}{ HIV-1 } & Env & SFV/Particles & Mouse & Humoral & {$[17]$} \\
\hline & gp41 & SFV/Particles & Mouse & Monoclonal Abs & {$[18]$} \\
\hline & $\mathrm{MA} / \mathrm{CA}$ & VEE/Particles & Mouse & Humoral, CTL & {$[19]$} \\
\hline \multirow[t]{2}{*}{ HPV } & $16 \mathrm{E} 7$ & SFV/DNA & Mouse & CTL & {$[34]$} \\
\hline & 16E7-VP22 & SIN/Particles & Mouse & $\mathrm{CD}^{+} \mathrm{T}$-cell response & {$[35]$} \\
\hline \multirow[t]{2}{*}{ HSV-1 } & gpB & SIN/Particles & Mouse & HSV protection & {$[36]$} \\
\hline & gpB & SIN/DNA & Mouse & CTL, protection & [37] \\
\hline IBDV & $\mathrm{VP} 2$ & SFV/Particles, DNA & Chicken & Specific Abs & {$[38]$} \\
\hline \multirow[t]{4}{*}{ Influenza } & HA & SFV/Particles & Mouse & Systemic response & {$[15]$} \\
\hline & HA & VEE/Particles & Chicken & Influenza protection & {$[16]$} \\
\hline & HA & VEE/Particles & Swine & Influenza protection & {$[20]$} \\
\hline & NP & SFV/Particles, RNA & Mouse & Humoral, CTL & [39] \\
\hline ISAV & $\mathrm{HE}$ & SAV/Particles & Salmon & ISAV protection & {$[40]$} \\
\hline JEV & prM-E, NS1-2A & SIN/Particles & Mouse & JEV Abs & {$[41]$} \\
\hline Lassa & $\mathrm{N}$ & VEE/Particles & Mouse & Immune response & {$[42]$} \\
\hline \multirow[t]{2}{*}{ LIV } & prME & SFV/Particles & Mouse & LIV protection & {$[43]$} \\
\hline & prME, NS1 & SFV/Particles & Sheep & LIV protection & {$[44]$} \\
\hline \multirow[t]{2}{*}{ MBGV } & GP, NP, VP35 & VEE/Particles & Guinea pig & MBGV protection & {$[45]$} \\
\hline & GP, NP & VEE/Particles & Macaque & MBGV protection & {$[46]$} \\
\hline \multirow[t]{2}{*}{ Measles } & HA, FUd & SIN/DNA & Mouse & Measles protection & {$[47]$} \\
\hline & HA, FUd & SIN-VEE/Particles & Macaque & Measles protection & {$[48]$} \\
\hline MVE & prME, E & SFV/Particles & Mouse & Neutralizing Abs & [49] \\
\hline $\mathrm{NiV}$ & Glycoproteins & VEE/Particles & Mouse & Neutralizing Abs & {$[33]$} \\
\hline NLV & VLP & VEE/Particles & Mouse & Immune response & {$[50]$} \\
\hline Rabies & $\mathrm{G}$ & SIN/DNA & Mouse & Rabies protection & {$[51]$} \\
\hline \multirow[t]{2}{*}{ RSV } & $\mathrm{F}, \mathrm{G}$ & SFV/DNA, RNA & Mouse & RSV protection & {$[52]$} \\
\hline & $\mathrm{F}, \mathrm{G}$ & SFV/Particles & Mouse & RSV protection & [53] \\
\hline
\end{tabular}


Table 1. Cont.

\begin{tabular}{|c|c|c|c|c|c|}
\hline Virus & Target & Vector/Delivery & Immunization & Response & Reference \\
\hline RVFV & Gn & VEE/Particles & Mouse & RVFV protection & {$[54]$} \\
\hline SARS-CoV & Glycoprotein & VEE/Particles & Mouse & SARS-CoV protection & {$[55]$} \\
\hline SEOV & M, S & SIN/Particles, DNA & Hamster & SEOV protection & {$[56]$} \\
\hline SHIV & Env & SFV/Particles & Macaque & T-cell proliferative response & {$[57]$} \\
\hline SUDV & GP & VEE/Particles & Primate & SUDV protection & {$[58]$} \\
\hline Vaccinia & A33R, B5R & VEE/Particles & Mouse & Vaccinia protection & {$[59]$} \\
\hline
\end{tabular}

Abbreviations: Abs, antibodies; BVDV, bovine viral diarrhea virus; CMI, cell-mediated immune response; CMV, cytomegalovirus; CSFV, classical swine fever virus; CTL, cytotoxic T-lymphocyte activity; HBV, hepatitis B virus; $\mathrm{HBC}$, hepatitis C virus; HE, hemagglutinin-esterase; HeV, Hendra virus; HIV, human immunodeficiency virus; HPV, human papillomavirus; HSV, herpes simplex virus; IBDV, infectious bursal disease virus; ISAV, infectious salmon anemia virus; JEV, Japanese encephalitis virus; LIV, Louping-ill virus; MBGV, Marburg virus; MVE, Murray Valley encephalitis virus; NiV, Nipah virus; NLV, Norwalk-like virus; RSV, respiratory syncytial virus; RVFV, Rift Valley fever virus; SARS-CoV, severe acute respiratory syndrome corona virus; SAV, salmon anemia virus; SEOV, Seoul virus; SFV, Semliki Forest virus; SHIV, simian-human immunodeficiency virus; SIN, Sindbis virus; SUDV, Sudan virus; VEE, Venezuelan equine encephalitis virus.

Attempts to further improve the immunogenicity of vaccine candidates, the herpes simplex virus type I (HSV-1) VP22 protein was fused to the H5N1 subtype influenza HA [60]. The responses of both

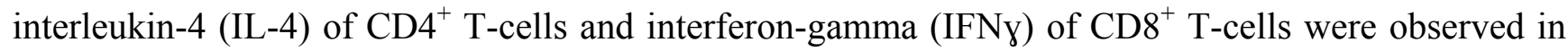
vaccinated mice. VEE replicon particles expressing the severe acute respiratory syndrome coronavirus (SARS-CoV) glycoprotein managed to provide protection against challenges with lethal doses of SARS-CoV in vaccinated mice [55]. Furthermore, VEE particles were applied for the expression of glycoproteins from the zoonotic pathogenic Hendra virus $(\mathrm{HeV})$ and Nipah virus $(\mathrm{NiV})$, known to cause fatal infections in both animals and humans [33]. Immunization resulted in enhanced induction of cross-reactive neutralizing antibodies. In another study, mice were vaccinated with both DNA plasmids and alphavirus replicons expressing Rift Valley fever virus (RVFV) glycoprotein Gn fused to the C3d complement protein [54]. The immunization generated neutralizing antibodies and provided protection against challenges with RVFV, which suggested that plasmid DNA and alphavirus replicon approaches, as well as the combined DNA prime/replicon boost strategy show great promise for valid RVFV vaccine development. The combined approach included plasmid vaccinations at Weeks 0 and 3 followed by a replicon boost at Week 6 .

In a combined vaccine approach, SFV DNA vectors and recombinant adenovirus expressing the classical swine fever virus (CSFV) E2 glycoprotein elicited higher titers of neutralizing antibodies in pigs [26]. After challenges with the virulent CSFV Shimen strain, no symptoms of viremia were observed, for the combined vaccine, whereas vaccination with adenovirus alone resulted in viremia in one pig of five. Furthermore, sequential immunization with SIN and VEE replicon particles expressing the type 1 HIV gp140 envelope (Env) and trimeric Env protein in MF59 adjuvant provided partial protection in macaques against intravenous challenges with high doses of simian-human immunodeficiency virus (SHIV) [61]. The administration could be further extended to intramuscular and mucosal delivery [62]. Different degrees of protection were observed against challenges with SHIV after mucosal administration. In contrast, intramuscular vaccination rendered macaques to be 
completely resistant to SHIV. In cotton rats, SIN DNA vectors carrying the hemagglutinin (pMSIN-H) and fusion proteins (pMSINH-FdU) elicited neutralizing antibodies, mucosal and systemic antibody-secreting cells, memory B-cells and IFNr secreting T-cells [47]. Priming with pMSIN-H provided $100 \%$ protection against challenges with pulmonary measles. However, pMSINH-FdU priming was observed only after a boost with live measles virus vaccine. In another study, chimeric VEE/SIN replicon particles were applied for the expression of measles virus hemagglutinin $(\mathrm{H})$ and fusion (F) proteins, which elicited high-titer neutralizing antibody and IFNr-producing T-cells in macaques after intradermal vaccination [48]. Protection from rash and viremia was obtained after challenges with wild-type measles virus 12-17 months after vaccination. Alphaviruses have also been subjected to the development of smallpox vaccines by the introduction of A33R, B5R, A27L and L1R genes into VEE particles [59]. Vaccinated mice showed protective immunity. Furthermore, vaccination of macaques elicited strong antibody responses and was capable of neutralizing and inhibiting the spread of vaccinia and monkey pox viruses. SIN-based DNA vaccines have been developed against rabies [51]. In comparison to a conventional rabies DNA vaccine, the SIN DNA vaccine induced better humoral and cell-mediated immune responses in immunized mice and showed complete protection against challenge with the CVS rabies strain.

Recently, novel hepatitis $\mathrm{C}$ virus (HCV) vaccine candidates were developed by expressing all or a part of the HCV non-structural proteins (nsPs) from an SFV vector [32]. An insert as large as $6.1 \mathrm{~kb}$ allowed the expression of all nsPs leading to a strong and long-lasting NS3-specific CD8 ${ }^{+} \mathrm{T}_{\text {-cell }}$ response. The level of T-cell response was similar to that observed for the expression of only NS3/4A. Immunization demonstrated significant growth delay of HCV-expressing EL4 tumors in a mouse model. In another study, glycoproteins for either Sudan virus (SUDV) or Ebola virus were expressed from VEE replicons and evaluated in vaccinated nonhuman primates [58]. A single intramuscular injection with VEE particles expressing SUDV GP provided complete protection against challenges with SUDV in cynomolgus macaques. However, VEE-SUDV GP vaccinated primates were not fully protected against back challenges with Ebola virus. On the other hand, co-injection of VEE particles expressing SUFV GP and Ebola virus GP showed protection against both virus types.

Recently, VEE replicon particles generated in Vero cells were used to express the E2 glycoprotein of bovine viral diarrhea virus (BVDV) [23]. Vaccination of BVDV free calves with $1 \times 10^{6}$ IU and $1 \times 10^{7} \mathrm{IU}$, respectively, resulted in neutralizing antibody titers, which were able to cross-neutralize both type 1 and type 2 BVDV genotypes after booster immunizations. Vaccination with the higher dose significantly reduced the viral-based leukopenia and showed some protection from clinical disease. Similarly, VEE replicon particles were engineered to express Dengue virus E antigen in two configurations as subviral particles (prME) and soluble dimers (E85) [27]. Immunization of macaques resulted in the rapid production of neutralizing antibodies and demonstrated protection against challenges with Dengue virus. Moreover, the tetravalent E85 VEE replicon particle vaccine induced a protective response to all four Dengue virus serotypes when two immunizations were administered six weeks apart.

A novel approach has been to combine alphavirus replicons with pseudotyped baculovirus [63]. In this context, pseudotyped baculovirus vectors containing the hybrid CM promoter and SFV replicon were used for the expression of GP5 and M proteins of porcine reproductive and respiratory syndrome virus (PRRSV) and compared to a pseudotyped baculovirus vector carrying only a CMV promoter. 
Immunization with the hybrid CMV/SFV showed the induction of strong GP5-specific antibodies, and in general, the Th1-dominant immune response was stronger than the one elicited by the CMV promoter alone.

Veterinary medicine has also gained from alphavirus vaccine development. In this context, salmonid alphavirus (SAV) replicons were applied for the expression of infectious salmon anemia virus (ISAV) hemagglutinin-esterase (HE) [40]. Intramuscular administration of SAV replicons provided protection against challenges with ISAV in Atlantic salmon. In contrast, intraperitoneal injection was not successful [64]. In another study, DNA vaccines based on the SAV E1 and E2 spike proteins were compared to whole virus vaccine in Atlantic salmon [65]. The whole virus vaccine showed superior immunogenicity to the DNA vaccine; the latter provided only marginal reduction in viral replication, and the protection against SAV challenges was no different from controls.

\section{Non-Viral Targets}

Alphavirus-based vaccine development has also been addressed for a number of other infectious pathogens (Table 2). For instance, SFV vectors were employed for the expression of the Plasmodium falciparum Pf332 antigen, which elicited immunological memory in vaccinated mice [66]. Moreover, vaccination of mice with SIN plasmid DNA vectors carrying the Mycobacterium tuberculosis 85A antigen (Ag85A) provided strong immunity and resulted in long-term protection against $M$. tuberculosis challenges [67]. In another approach, using SFV DNA replicons, the botulinum neurotoxin A Hc (BoNTA-Hc) gene provided both antibody and lymphoproliferative responses in vaccinated BALB/c mice [68]. The immunogenicity was enhanced when granulocyte-macrophage colony-stimulating factor (GM-CSF) was co-expressed as an adjuvant. Additionally, replication-deficient SFV particles were used for the expression of the Brucella abortus translation initiation factor 3 (IF3) [69]. Immunization of BALB/c mice demonstrated significant levels of protection against challenges with the virulent B. abortus strain 2308. Similarly, protective antigen (PA) for Bacillus anthracis were expressed from SIN vectors, resulting in specific and neutralizing antibodies in Swiss Webster mice and offered some protection against challenges with lethal doses of the pathogenic bacteria [70].

Table 2. Alphavirus-based vaccine development for non-viral infectious agents.

\begin{tabular}{|c|c|c|c|c|c|}
\hline Agent & Target & Vector/Delivery & Immunization & Response & Reference \\
\hline B. anthracis & PA & SIN/Particles & Mouse & B. anthracis protection & {$[70]$} \\
\hline B. abortus & IF3 & SFV/Particles & Mouse & Brucella protection & {$[69]$} \\
\hline C. botulinum & BoNTA-Hc & SFV/DNA & Mouse & $\left.\begin{array}{c}\text { Abs, lymphoproliferative } \\
\text { response }\end{array}\right][68]$ \\
\hline Malaria & CS & SIN/Particles & Mouse & Malaria protection & {$[71]$} \\
\hline M. tuberculosis & Ag85A & SIN/DNA & Mouse & Protection & {$[67]$} \\
\hline P. falciparum & Ag Pf332 & SFV/Particles-RNA & Mouse & Immunological memory & {$[66]$} \\
\hline Prion & NP & SFV/Particles & Mouse & Monoclonal Abs & {$[72]$} \\
\hline Staphylococcus & enterotoxin B & VEE/Particles & Mouse & Protection & {$[73]$} \\
\hline
\end{tabular}

Abbreviations: Abs, antibodies; SFV, Semliki Forest virus; SIN, Sindbis virus; VEE, Venezuelan equine encephalitis virus. 


\section{Tumor Vaccine Approaches}

Alphaviruses have found frequent applications in the area of tumor vaccine development (Table 3). In this context, naked RNA, replication-deficient particles and DNA layered vectors have been employed as delivery vehicles. For instance, mice have been subjected to immunization with naked SFV RNA replicons carrying the LacZ gene [74]. Interestingly, a single injection of only $1 \mu \mathrm{g}$ of SFV-LacZ RNA presented complete tumor protection. Furthermore, when tumors were administered two days prior to the immunization, the survival was extended by 10-20 days. Among DNA-based tumor vaccine approaches, SIN vectors expressing mouse and human tyrosine-related protein-1 (TRP-1) were evaluated in a B16 mouse melanoma model [75]. Intramuscular injection was capable of breaking immune tolerance and provided protection against melanoma when mice were vaccinated five days prior to cancer challenge. In another study, alphavirus replicon-based expression of melanoma differentiation antigen (MDA) tyrosine demonstrated the inhibition of the growth of B16 transplantable melanoma [76]. In this context, the vaccine encoding tyrosine related protein 2 (TRP-2) relied on a novel immune mechanism, which required the activation of both $\operatorname{IgG}$ and $\mathrm{CD} 8^{+}$cell effector responses.

Table 3. Alphavirus-based vaccine development for cancer targets.

\begin{tabular}{|c|c|c|c|c|c|}
\hline Target & Gene & Vector/Delivery & Immunization & Response & Reference \\
\hline \multirow[t]{9}{*}{ Brain tumor } & IL-12 & SFV/Particles & Mouse & Immunogenicity & [77] \\
\hline & Endostatin & SFV/Particles & Mouse & $\begin{array}{l}\text { Inhibited tumor } \\
\text { growth }\end{array}$ & {$[78]$} \\
\hline & LacZ & SFV/Particles & Mouse & Tumor protection & [79] \\
\hline & gp100, IL-18 & SIN/DNA & Mouse & Tumor protection & {$[80]$} \\
\hline & HER2/neu & SIN/DNA & Mouse & Tumor protection & {$[81]$} \\
\hline & HER2/neu & SIN/DNA & Mouse & Tumor protection & {$[82]$} \\
\hline & HER2/neu & SIN/DNA, paclitaxel & Mouse & Tumor regression & {$[83]$} \\
\hline & $\mathrm{Neu}$ & VEE/Particles & Rat & $\begin{array}{l}\text { Anti-tumor } \\
\text { immunity }\end{array}$ & {$[84]$} \\
\hline & $\mathrm{Neu}$ & VEE /Particles, DCs & Mouse & Tumor regression & {$[85]$} \\
\hline \multirow[t]{6}{*}{$\begin{array}{c}\text { Cervical } \\
\text { cancer }\end{array}$} & HPVE6-E7 & SFV/Particles & Mouse & Tumor protection & {$[86]$} \\
\hline & HPVE6-E7 & SFV/Particles & Mouse & Tumor regression & {$[87]$} \\
\hline & HPV-CRT & SIN/Particles & Mouse & Tumor protection & {$[88]$} \\
\hline & HPVE7 & VEE/Particles & Mouse & Tumor protection & {$[89]$} \\
\hline & HPVE6E7+IL12 & SFV/Particles & Mouse & Anti-tumor activity & {$[90]$} \\
\hline & HPVE7-VP22 & SIN/Particles & Mouse & $\begin{array}{c}\mathrm{CD} 8^{+} \mathrm{T} \text {-cell } \\
\text { response }\end{array}$ & {$[91]$} \\
\hline Colon cancer & SFV vector & SFV/Particles & Mouse & Anti-tumor effect & {$[92]$} \\
\hline Endothelial & VEGFR-2 & SFV/Particles & Mouse & Antibody response & [93] \\
\hline Glioma & $\mathrm{B} 16,203$ & SFV/Particles & Mouse & Tumor protection & {$[94]$} \\
\hline Kidney cancer & IL-12 & $\begin{array}{c}\text { SFV/Encapsulated } \\
\text { particles }\end{array}$ & Human Phase I & $\begin{array}{c}\text { 5-fold IL-12 } \\
\text { expression }\end{array}$ & {$[95]$} \\
\hline Melanoma & MDA/trp-2 & VEE/Particles & Mouse & Therapeutic effect & {$[76]$} \\
\hline
\end{tabular}


Table 3. Cont.

\begin{tabular}{|c|c|c|c|c|c|}
\hline Target & Gene & Vector/Delivery & Immunization & Response & Reference \\
\hline & IL-12 & SFV/Particles & Mouse & Tumor eradication & {$[96]$} \\
\hline & IL-12 & $\begin{array}{c}\text { SFV/Encapsulated } \\
\text { particles }\end{array}$ & Human Phase I & $\begin{array}{c}\text { 5-fold IL-12 } \\
\text { expression }\end{array}$ & {$[95]$} \\
\hline & MUC18/MCAM & SIN/DNA & Mouse & Tumor protection & {$[97]$} \\
\hline Metastatic & CEA & VEE/Particles & Human Phase I & $\begin{array}{c}\text { CEA Abs, extended } \\
\text { survival }\end{array}$ & {$[98]$} \\
\hline & PSMA & VEE/Particles & Human Phase I & PSMA Abs & {$[99]$} \\
\hline Prostate cancer & PSMA & VEE/Particles & Mouse & Tumor response & {$[100]$} \\
\hline & STEAP & VEE/DNA & Mouse & Anti-tumor response & {$[101]$} \\
\hline & PSCA & VEE/Particles & Mouse & Tumor protection & {$[102]$} \\
\hline Tumor & $\beta$-galactosidase & SFV/RNA & Mouse & Tumor protection & {$[74]$} \\
\hline & IL-12 & SFV/Particles & Mouse & Tumor protection & {$[103]$} \\
\hline Tumor antigen & MHC class II & SFV/Particles-DNA & Mouse & Immunogenicity & {$[104]$} \\
\hline & P815 & SFV/Particles & Mouse & $\begin{array}{c}\text { CTL, tumor } \\
\text { protection }\end{array}$ & {$[105]$} \\
\hline & trp-1 & SIN/DNA & Mouse & Antitumor activity & {$[91]$} \\
\hline
\end{tabular}

Abbreviations: CEA, carcinoembryonic antigen; CRT, calreticulin; CTL, cytotoxic T-lymphocyte activity; DCs, dendritic cells; HPV, human papillomavirus; IL, interleukin; MCAM, melanoma cell adhesion molecule; MDA, melanoma differentiation antigen; MHC, major histocompatibility complex; PSCA, prostate stem cell antigen; PSMA, prostatespecific membrane antigen; SFV, Semliki Forest virus; SIN, Sindbis virus; STEAP, six-transmembrane epithelial antigen of the prostate; trp, tyrosine-related protein; VEE, Venezuelan equine encephalitis virus.

Furthermore, vaccination with recombinant particles expressing the P1A gene [105] and the human papilloma virus (HPV) E7 gene [89] from SFV and VEE vectors, respectively, provided protection against further tumor development in mice. Attempts have also been made to improve the efficacy of SFV-based HPV vaccines by supplying SFV-based IL-12 expression in mice [90]. At low doses, IL-12 stimulated antigen-specific CTL responses and enhanced anti-tumor responses after SFV-based HPV16-E6E7 immunization. Subsequent increases in dosage, however, neither improved the immune responses, nor tumor regression. SIN DNA vectors have been employed for the expression of the murine melanoma cell adhesion molecule (MCAM/MUC18) as a vaccine against murine melanoma, which resulted in the induction of humoral and $\mathrm{CD} 8^{+} \mathrm{T}$-cell immune responses against melanoma [97].

In the context of breast cancer, a DNA-based SIN vector expressing the neu gene was applied for intramuscular vaccination of mice 14 days prior to the injection of cancer cells overexpressing neu [81]. The immunization provided strong protection against tumor development. The incidence of lung metastasis from mammary fat pad tumors was reduced. Moreover, the number of lung metastases from intravenous injection of neu overexpressing cells decreased. Additionally, intradermal vaccination provided tumor protection applying $80 \%$ less plasmid than required for conventional DNA vectors. Further confirmation of successful cancer vaccination was obtained from the administration of SIN vectors expressing neu (pSINCP/neu) in a murine breast tumor model [82]. However, in this case, the prophylactic vaccine only showed efficacy when administered prior to the tumor challenge. Another approach was comprised of combining alphavirus-based delivery with the chemical anticancer 
agent, doxorubicin [83]. When pSINCP/neu DNA and VEE/neu particles were administered after injection of $5 \mathrm{mg} / \mathrm{kg}$ of doxorubicin, the tumor progression was significantly delayed. This phenomenon did not occur for doxorubicin alone. Similarly, a combination therapy with paclitaxel (25 $\mathrm{mg} / \mathrm{kg}$ ) and $\mathrm{pSINCP} / \mathrm{neu}$ was ineffective. Moreover, VEE-neu particles were subcutaneously administered in a rat mammary tumor model, which resulted in the elimination of $36 \%$ of pre-existing aggressive mammary tumors [84]. The combination of dendritic cell (DC)-based cancer immunotherapy with VEE-neu particle administration induced both cellular and humoral immunity against neu in transgenic human breast tumor-bearing mice [85]. Moreover, this treatment resulted in the significant inhibition of tumor growth. Similarly, both tumor growth and pulmonary metastatic spread were significantly inhibited when mice with pre-existing tumors were subjected to five immunizations with SFV10-E VLP expressing the vascular endothelial growth factor receptor 2 (VEGFR-2) [93]. Furthermore, co-immunization with SFV particles encoding VEGFR-2 and IL-4 generated significant tumor regression in mice.

Lung cancer has also been targeted by combined therapy with SFV-IL-12 particles and anti-CD137 monoclonal antibodies [96]. Syngeneic TC-1 lung carcinoma was inhibited after intratumoral SFV-IL-12 administration and co-stimulation with anti-CD137 mAbs. In the context of colon cancer vaccines, a SIN-based DNA vector carrying the LacZ gene was compared to conventional plasmid DNA vectors in mice with CT26.CL25 tumors [106]. Intramuscular immunization elicited immune responses at doses 100- to 1,000-fold lower for the SIN DNA replicon vector compared to the conventional CMV-promoter-based DNA-LacZ vector. Similarly, SFV particles providing VEGFR-2 expressing in vaccinated mice inhibited CT26 colon carcinoma growth [93]. Closer analysis of microvessel density demonstrated that a significant inhibition of tumor angiogenesis occurred. Additionally, when mice were co-immunized with SFV-VEGFR-2 and SFV-IL-4 particles, their survival rate was significantly enhanced. Furthermore, oncolytic SFV vectors have been used for immune stimulation in a CT26 colon tumor model [92]. Intratumoral injections led to an immediate and intense inflammatory reaction and a significant improvement in survival rates. SFV particles expressing HPV16 E6 and E7 have been subjected to prophylactic vaccine development in a murine TC-1 model for cervical cancer [107]. Pre-immunization with a low dose $\left(10^{4}\right.$ particles) resulted in an HPV-specific CTL response in 50\% of mice, whereas a higher dose $\left(10^{6}\right.$ particles) elicited CTL responses in all animals. Furthermore, at a dose of $5 \times 10^{6}$ particles, $40 \%$ of mice were protected from tumor challenges. In another study, the SFV-enhE6,7 particle vaccine showed its potential after intravenous and intramuscular delivery, where exponentially growing tumors completely resolved [87]. Similarly, SIN virus RNA replicons expressing HPV E7 were evaluated in a TC-1 mouse model [108]. The humoral and cellular immune responses were poor, and no tumor protection was obtained; but, when the HPV E7 gene was fused to the secretory Sig protein and lysosome-associated membrane protein 1 (LAMP-1), enhanced E7-specific $\mathrm{CD}^{+}$helper T-cell and $\mathrm{CD}^{+}$cytotoxic T-cell activity was observed. Moreover, strong in vivo anti-tumor activity was induced. In another study, SIN virus particles expressing both HPV E7 and calreticulin (CRT), an endoplasmic reticulum $\mathrm{Ca}^{2+}$ binding transporter, were tested as prophylactic vaccines [88]. Vaccinations generated antigen-specific immune responses, an anti-angiogenic effect and a strong anti-tumor activity. Furthermore, intramuscular immunization one week prior to challenge with TC-1 carcinoma cells provided protection to all treated mice. Also VEE particles expressing HPV E7 were subcutaneously injected in mice two weeks prior to cancer cell inoculation, which prevented 
tumor formation [89]. Furthermore, vaccination induced long-term memory, as protection was observed for challenges three months after the immunization. The therapeutic efficacy was only $67 \%$ of treated tumor-bearing mice. However, co-expression of HPV E6 and E7 from the same vector significantly enhanced the therapeutic effect $[109,110]$.

In a prostate tumor model, VEE particles expressing human prostate-specific membrane antigen (PSMA) showed strong cellular and humoral immunity after subcutaneous administration [100]. Furthermore, VEE particles have been employed for the expression of the predominantly prostate tissue-specific six transmembrane epithelial antigen of the prostate (STEAP) [101]. Pre-immunization with VEE-STEAP particles induced a specific immune response and significantly prolonged the overall survival of mice bearing TRAMPC-2 tumors. When TRAMP mice were prophylactically immunized with a prostate stem cell antigen (PSCA) DNA plasmid followed by VEE-PSCA particle administration, a specific immune response and anti-tumor protection were observed in $90 \%$ of vaccinated animals [102]. Several vaccine studies have targeted brain tumors. For instance, SFV particles expressing endostatin showed a significant reduction of intratumoral vascularization after intratumoral delivery [78]. In another approach, bone-marrow isolated dendritic cells (DCs) were transduced with SFV vectors carrying cytokine genes of specific cDNAs from melanoma and glioma cells [79]. Pre-vaccination with DCs transduced with SFV-based B16 and 203 glioma cDNAs, respectively, resulted in tumor challenge protection and the prolonged survival of tumor-bearing mice. The combination of DCs transduced with SFV-IL-12 particles and systemically administered IL-18 also provided increased survival rates [111]. Moreover, the expression of human melanoma-associated antigen gp100 and IL-18 from a SIN virus DNA vector induced specific anti-tumor CTL responses and provided anti-tumor protection [80]. Vaccination prevented B16-hgp100 tumor formation and demonstrated significant prolongation of survival in mice with established B16-hgp100 tumors.

\section{Vaccines against Alphaviruses}

As alphaviruses have been suggested to be responsible for epidemics in various parts of the world, it has also become important to develop vaccines against alphaviruses themselves (Table 4). In this context, protection against airborne virus was observed in BALB/c mice vaccinated with an attenuated VEE strain [112]. In another study, improved protection against VEE challenges was achieved by using a live attenuated V3526 VEE vaccine [113]. Similarly, when a chimeric Eastern equine encephalitis (EEE) and Western equine encephalitis (WEE) virus were applied for the vaccination of C57BL/6 mice, complete protection was observed against lethal challenges with a virulent Eastern equine encephalitis (EEE) virus strain [114].

Table 4. Alphavirus-based vaccine development against alphaviruses.

\begin{tabular}{|c|c|c|c|c|c|}
\hline Virus & Gene & Vector Delivery & Immunization & Response & Reference \\
\hline CHIK & TSI-GSD-218 & CHIK infection & Human Phase II & Neutralizing Abs & {$[115]$} \\
\hline CHIK & Glycoprotein & CHIK infection & Macaques & Neutralizing Abs & {$[116]$} \\
\hline CHIK & IRES & CHIK infection & Vero cells & Mosquito resistance & {$[117]$} \\
\hline CHIK & C, E1 VLPs & CHIK infection & Primates & CHIK protection & {$[118]$} \\
\hline CHIK & nsP3, E1 siRNA & CHIK infection & Vero cells & Reduced CHIK titer & {$[119]$} \\
\hline CHIK & miRNAs & CHIK infection & Mouse & Reduced CHIK replication & {$[120]$} \\
\hline
\end{tabular}


Table 4. Cont.

\begin{tabular}{|c|c|c|c|c|c|}
\hline Virus & Gene & Vector Delivery & Immunization & Response & Reference \\
\hline EEE & EEE/WEE & EEE infection & Mouse & EEE protection & {$[114]$} \\
\hline VEE & VEE att & VEE infection & Mouse & VEE protection & {$[112]$} \\
\hline VEE & VEE V3526 & VEE infection & Mouse & VEE protection & {$[113]$} \\
\hline VEE & VEE TC-83 & VEE infection & Mouse & VEE protection & {$[121]$} \\
\hline VEE & $26 S$ & VEE infection & Macaques & VEE protection & {$[122]$} \\
\hline VEE & CHIK genes & Chimeric VEE-CHIK & Mosquito & Reduced infectivity & {$[123]$} \\
\hline VEE & RdRp miRNA & VEE infection & BHK cells & Inhibition of VEE replication & {$[124]$} \\
\hline WNV & WNV att & WNV Nanopatch & Mouse & Abs & {$[125]$} \\
\hline
\end{tabular}

Abbreviations: Abs, antibodies; att, attenuated; C, capsid; CHIK, Chikungunya virus; EEE, Eastern equine encephalitis virus; miRNA, micro-RNA; RdRp, RNA-dependent RNA polymerase; SFV, Semliki Forest virus; SIN, Sindbis virus; siRNA, short interfering RNA; VEE, Venezuelan equine encephalitis virus; VLPs, virus-like particles; WNV, West Nile virus.

In attempts to design attenuated alphaviruses for vaccine development, the mechanisms of replication and virus-host interaction have been investigated. In this context, mosquito transmission of Chikungunya (CHIK) virus has been prevented by making their replication dependent on internal ribosome entry sites (IRES) [117]. Although replication does not occur in mosquito cells, replication proceeds efficiently in Vero cells. In another approach, the non-structural genes of the attenuated VEE strain TC-83 and the naturally attenuated EEV strain, respectively, were engineered with the structural genes of CHIK [123]. The chimeric vaccine candidates presented a significantly reduced infectivity of the common urban Aedes aegypti and A. albopictus vectors for CHIK, thereby providing a low risk of virus transmission. A new CHIK virus isolated from an acutely infected human patient was used for the engineering of a synthetic DNA vaccine [116]. When this DNA vaccine was electroporated into mice, robust antigen-specific cellular and humoral responses were obtained, which provided protection against further challenges with CHIK. Furthermore, immunization of macaques demonstrated the induction of neutralizing antibodies similar to those elicited in sera from convalescent human patients. In another DNA vector approach, the VEE 26S structural genes were expressed and administered as an aerosol in nonhuman primates [122]. Vaccination resulted in no viremia in two macaques and low viremia in one animal, whereas it was high in all control animals.

In an approach to target epidermal and dermal antigen presenting cells (APCs), the Nanopatch (NP) technology has been applied for skin vaccination of West Nile virus and CHIK in mice [125]. NP, comprised of arrays of densely packed projections two orders of magnitude smaller than standard needles, provided efficient delivery of inactivated whole CHIK vaccine and a DNA-based West Nile virus vaccine. Moreover, as virus-like particles (VLPs) consisting of CHIK capsid and envelope proteins have been demonstrated to protect nonhuman primates against infection of multiple strains of CHIK, it was of benefit to screen and optimize the solution conditions for stable vaccine formulations [118]. In this context, sugar, sugar alcohols and polyanions were identified as potential stabilizers.

The relatively recent discovery of the commonly occurring phenomenon of gene silencing has also made its impact on vaccine development. In this context, small interfering RNAs (siRNAs) were engineered against two conserved regions of the nsP3 and E1 genes of CHIK [119]. A significant reduction of virus titer was observed in Vero cells after $24 \mathrm{~h}(99 \%)$ and $48 \mathrm{~h}$ (65\%), suggesting a 
potential new therapeutic approach. In another approach, microRNA (miRNA)-specific target sequences for replicon particle production were introduced into alphavirus helper RNAs [120]. In the presence of miRNA-specific inhibitors, CHIK particles were efficiently generated, whereas in their absence, cellular miRNAs downregulated helper RNA replication. When mice were inoculated with replicon RNA carrying engineered miRNA sequences, cellular miRNAs prevented the replication of replicon RNA, which opens the feasibility of using miRNAs as a therapeutic approach for the inhibition of viral replication. Moreover, the VEE RNA-dependent RNA polymerase (RdRp) was targeted by artificial miRNAs in attempts to inhibit VEE replication [124]. Of five miRNAs that were evaluated in BHK cells, three showed significant inhibition of VEE replication.

\section{Clinical Trials for Alphavirus Vaccines}

Despite the large number of studies conducted in various animal models, relatively few evaluations have been subjected to humans. A clinical trial conducted with alphaviruses involved intravenous administration of liposome encapsulated SFV particles expressing IL-12 particles to melanoma and kidney carcinoma patients [95]. High transient expression of recombinant IL-12 with a five-fold increase lasted for 4-7 days. As higher doses induced a fever response in patients, the maximum tolerated dose (MTD) was restricted to $3 \times 10^{9}$ encapsulated particles per $\mathrm{m}^{2}$. No liposome- or SFV-related toxicity was observed. Furthermore, the liposome-encapsulation prevented SFV particles from being recognized by the host immune system and, therefore, allowed repeated systemic administration. The phase I study clearly demonstrated the safe administration of encapsulated SFV particles.

A human phase II, randomized, double-blind, placebo-controlled, safety and immunogenicity study was conducted in 73 healthy adult volunteers on a serially passaged, plaque-purified, live CHIK vaccine [115]. A single subcutaneous injection of the CHIK vaccine was administered to 59 volunteers, and 14 individuals received placebo. There were no adverse events, except for transient arthralgia in five individuals receiving the CHIK vaccine. Of the 58 evaluable vaccinated individuals, 57 (98\%) developed CHIK neutralizing antibodies by Day 28 and 85\% still remained seropositive one year later. None of the individuals who received placebo were seropositive. In another vaccine-related alphavirus phase I randomized, double-blind clinical trial for cytomegalovirus (CMV), a two-component vaccine expressing $\mathrm{CMV} \mathrm{gB}$ or pp65/1E1 fusion protein was administered intramuscularly or subcutaneously in CMV seronegative adult volunteers [25]. The vaccination showed only mild to moderate local reactions and no clinically important changes. It induced neutralizing antibody and multifunctional $\mathrm{T}$-cell responses against CMV antigens.

In another clinical trial, alphavirus particles expressing the carcinoembryonic antigen (CEA) were repeatedly administered to patients with metastatic cancer [98]. CEA-specific antibodies were able to mediate antibody-dependent cellular cytotoxicity against tumor cells from human colorectal cancer metastases. Furthermore, patients with CEA-specific antibodies encouragingly showed extended overall survival. Similarly, VEE replicons expressing the prostate-specific membrane antigen (PSMA) were applied for a human trial of patients with metastatic cancers at five doses of $0.9 \times 10^{7} \mathrm{IU}$ or $3.6 \times 10^{7} \mathrm{IU}$ [99]. At the lower dose, no PSMA-specific cellular response was obtained, but a weak PSMA-specific signal was detected by ELISA. Disappointingly, the higher dose showed no 
PMSA-specific response. The trial demonstrated that while there was neither clinical benefit nor robust immune responses, there were no toxicities associated with the immunization, and the VEE-PMSA particles were well tolerated. However, as neutralizing antibodies were elicited, the dosing might be suboptimal, requiring some further optimization.

\section{Conclusions}

A number of vaccine development studies have been conducted using mainly the three most commonly applied alphavirus vectors, SFV, SIN and VEE. To demonstrate the variety of approaches available, replicon particles, naked RNA and layered DNA vectors have been employed. Each approach has commonly generated responses detected by cellular or humoral responses. In the case of vaccine development against lethal viruses (Table 1), non-viral infectious targets (Table 2) and tumors (Table 3) immunization has provided long-term protection against challenges with the disease-causing agents. Moreover, due to the pathogenicity of several alphaviruses, they are themselves credible targets for vaccine development. Therefore, a number of studies, particularly for VEE and CHIK (Table 4), have provided protection against challenges with virulent alphavirus strains.

The potential of alphaviruses causing global epidemics has placed additional concern on the needs of addressing biosafety issues. Generally, the strains used for vaccine development are attenuated. Furthermore, in the case using alphavirus particles, second generation helper vectors [126] or split helper systems [8] have been applied to prevent any production of wild-type-like replication-proficient particles through non-homologous recombination. Only recently alphavirus-based vaccines have been subjected to clinical trials. In this context, SFV vectors have been used for delivery of immunostimulatory genes. Furthermore, immunizations for the treatment of CMV and vaccinations against prostate and metastatic cancers have been conducted with alphavirus vectors and particles. The strength of applying alphaviruses is the generation of rapid transgene expression and the transient nature of expression. However, the full potential of alphavirus-based vaccines has not been explored yet. In the future, it is anticipated that additional, positive observations, particularly in the form of providing protection against challenges with lethal pathogens and tumors, will attract the enhanced application of alphaviruses for vaccine development.

\section{Conflicts of Interest}

The author declares no conflict of interest.

\section{References and Notes}

1. Strauss, J.H.; Strauss, E.G. The Alphaviruses: Gene Expression, Replication and Evolution. Micobiol. Rev. 1994, 58, 491-562.

2. Kelvin, A.A. Outbreak of Chikungunya in the Republic of Congo and the global picture. J. Infect. Dev. Countries 2011, 5, 441-444.

3. Mathiot, C.C.; Grimaud, G.; Garry, P. An outbreak of Semliki Forest virus infections in Central African Republic. Am. J. Trop. Med. Hyg. 1990, 42, 386-393. 
4. Weaver, S.C.; Salas, R.; Rico-Hesse, R. Remergence of epidemic Venezuelan equine encephalomyelitis in South America. VEE Study Group. Lancet 1996, 348, 436-440.

5. Liljeström, P.; Garoff, H. A new generation of animal cell expression vectors based on the Semliki Forest virus replicon. Biotechnology 1991, 9, 1356-1361.

6. Xiong, C.; Levis, R.; Shen, P.; Schlesinger, S.; Rice, C.M.; Huang, H.V. Sindbis virus: An efficient, broad host range vector for gene expression in animal cells. Science 1989, 243, 1188-1191.

7. Davis, N.L.; Brown, K.W.; Johnston, R.E. In vitro synthesis of infectious Venezuelan equine encephalitis virus RNA from a cDNA clone: Analysis of a viable deletion mutant. Virology 1989, 171, 189-204.

8. Smerdou, C.; Liljeström, P. Two-helper RNA system for production of recombinant Semliki Forest virus particles. J. Virol. 1999, 73, 1092-1098.

9. Lundstrom, K.; Schweizer, C.; Rotmann, D.; Hermann, D.; Schneider, E.M. Semliki Forest virus vectors: efficient vehicles for in vitro and in vivo gene delivery. FEBS Lett. 2001, 504, 99-103.

10. Lundstrom, K. Semliki Forest virus vectors for rapid and high-level expression of integral membrane proteins. Biochim. Biophys. Acta 2003, 1610, 90-96.

11. Ehrengruber, M.U.; Lundstrom, K.; Schweitzer, C.; Heuss, C.; Schlesinger, S.; Gähwiler, B.H. Recombinant Semliki Forest virus and Sindbis virus infect efficiently neurons in hippocampal slice cultures. Proc. Natl. Acad. Sci. USA 1999, 96, 7041-7046.

12. Lundstrom, K.; Richards, J.G.; Pink, J.R.; Jenck, F. Efficient in vivo expression of a reporter gene in rat brain after injection of recombinant replication-deficient Semliki Forest virus. Gene Ther. Mol. Biol. 1999, 3, 15-23.

13. Lundstrom, K. Alphavirus vectors for vaccine production and gene therapy. Exp. Rev. Vacc. 2003, 2, 447-459.

14. Tonkin, D.R.; Whitmore, R.; Johnston, R.E.; Barro, M. Infected dendritic cells are sufficient to mediate the adjuvant activity generated by Venezuelan equine encephalitis virus replication particles. Vaccine 2012, 30, 4532-4542.

15. Malone, J.G.; Berglund, P.J.; Liljestrom, P.; Rhodes, G.H.; Malone, R.W. Mucosal immune responses associated with polynucleotide vaccination. Behring Inst. Mitt. 1997, 98, 63-72.

16. Schultz-Cherry, S.; Dybing, J.K.; Davis, N.L.; Williamson, C.; Suarez, D.L.; Johnston, R.; Perdue, M.L. Influenza virus (A/HK/156/97) hemagglutinin expressed by an alphavirus replicon system protects against lethal infection with Hong Kong-origin H5N1 viruses. Virology 2000, 278, 55-59.

17. Brand, D.; Lemiale, F.; Turbica, I.; Buzelay, L.; Brunet, S.; Branet, F. Comparative analysis of humoral immune responses to HIV type 1 envelope glycoproteins in mice immunized with a DNA vaccine, recombinant Semliki Forest virus RNA, or recombinant Semliki Forest virus particles. AIDS Res. Hum. Retroviruses 1998, 14, 1369-1377.

18. Giraud, A.; Ataman-Onal, Y.; Battail, N.; Piga, N.; Brand, D.; Mandrand, B.; Verrier, B. Generation of monoclonal antibodies to native human immunodeficiency virus type 1 envelope glycoprotein by immunization of mice with naked RNA. J. Virol. Methods 1999, 79, 75-84. 
19. Caley, I.J.; Betts, M.R.; Irlbeck, D.M.; Davis, N.L.; Swanstrom, R.; Frelinger, J.A.; Johnston, R.E. Humoral, mucosal, and cellular immunity in response to a human immunodeficiency virus type 1 immunogen expressed by a Venezuelan equine encephalitis virus vaccine vector. J. Virol. 1997, 71, 3031-3038.

20. Bosworth, B.; Erdman, M.M.; Stine, D.L.; Harris, I.; Irwin, C.; Jens, M.; Loynachan, A.; Kamrud, K.; Harris, D.L. Replicon particle vaccine protects swine against influenza. Comp. Immunol. Microbiol. Infect. Dis. 2010, 33, e99-e103.

21. Wilson, J.A.; Hart, M.K. Protection from Ebola virus mediated by cytotoxic T-lymphocytes specific for the viral nucleoprotein. J. Virol. 2001, 75, 2660-2664.

22. Pushko, P.; Bray, M.; Ludwig, G.V.; Parker, M.; Schmaljohn, A.; Sanchez, A.; Jahrling, P.B.; Smith, J.F. Recombinant RNA replicons derived from attenuated Venezuelan equine encephalitis virus protect guinea pigs and mice from Ebola hemorrhagic fever virus. Vaccine 2000, 19, $142-153$.

23. Loy, J.D.; Grander, J.; Mogler, M.; Vander Veen, R.; Ridpath, J; Harris, D.H.; Kamrud, K. Development and evaluation of a replicon particle vaccine expressing the E2 glycoprotein of bovine viral diarrhea virus (BVDV) in cattle. Virol. J. 2013, 10, e35.

24. Reddy, J.R.; Kwang, J.; Varthakavi, V.; Lechtenberg, K.F.; Minocha, H.C. Semiliki forest virus vector carrying the bovine viral diarrhea virus NS3 (p80) cDNA induced immune responses in mice and expressed BVDV protein in mammalian cells. Comp. Immunol. Microbiol. Infect. Dis. 1999, 22, 231-246.

25. Bernstein, D.I.; Reap, E.A.; Katen, K.; Watson, A.; Smith, K.; Norberg, P.; Olmsted, R.A.; Hoeper, A.; Morris, J.; Negri, S.; et al. Randomized, double-blind, Phase 1 trial of an alphavirus replicon vaccine for cytomegalovirus in CMV seronegative adult volunteers. Vaccine 2009, 28, 484-493.

26. Sun, Y.; Li, N.; Li, H.Y.; Li, M.; Qiu, H.J. Enhanced immunity against classical swine fever in pigs induced by prime-boost immunization using an alphavirus replicon-vectored DNA vaccine and a recombinant adenovirus. Vet. Immunol. Immunopathol. 2010, 137, 20-27.

27. White, L.J.; Sariol, C.A.; Mattocks, M.D.; Wahala, M.P.B.W.; Yingsiwaphat, V.; Collier, M.L.; Whitley, J.; Mikkelsen, R.; Rodriguez, I.V.; Martinez, M.I.; et al. An alphavirus vector-based tetravalent dengue vaccine induces a rapid and protective immune response in macaques that differs qualitatively from immunity induced by live virus infection. J. Virol. 2013, 87, 3409-3424.

28. Wilson, J.A.; Bray, M.; Bakken, R.; Hart, M.K. Vaccine potential of Ebola virus VP24, VP30, VP35, and VP40 proteins. Virology 2001, 286, 384-390.

29. Driver, D.A.; Latham, E.M.; Polo, J.M.; Belli, B.A.; Banks, T.A.; Chada, S.; Brumm, D.; Chang, S.M.; Mento, S.J.; Dolly, D.J.; et al. Layered amplification of gene expression with a DNA gene delivery system. Ann. N. Y. Acad. Sci. 1995, 772, 261-264.

30. Vidalin, O.; Fournillier, A.; Renard, N.; Chen, M.; Depla, E.; Boucreux, D.; Brinster, C.; Baumert, T.; Nakano, I.; Fukuda, Y.; et al. Use of conventional or replicating nucleic acid-based vaccines and recombinant Semliki forest virus-derived particles for the induction of immune responses against hepatitis $\mathrm{C}$ virus core and E2 antigens. Virology 2000, 276, 259-270. 
31. Brinster, C.; Chen, M.; Boucreux, D.; Paranhos-Baccala, G.; Liljeström, P.; Lemmonier, F.; Inchasupé, G. Hepatitis $\mathrm{C}$ virus non-structural protein 3-specific cellular immune responses following single or combined immunization with DNA or recombinant Semliki Forest virus particles. J. Gen. Virol. 2002, 83, 369-381.

32. Ip, P.P.; Boerma, A.; Regts, J.; Meijerhof, T.; Wilschut, J.; Nijman, H.V.; Daemen, T. Alphavirus-based vaccines encoding non-structural proteins of Hepatitis $\mathrm{C}$ virus induce robust and protective T cell responses. Mol. Ther. 2013, doi:10.1038/mt.2013.287.

33. Defang, G.N.; Khetawat, D.; Broder, C.C.; Quinnan, G.V., Jr. Induction of neutralizing antibodies to Hendra and Nipah glycoproteins using a Venezuelan equine encephalitis virus in vivo expression system. Vaccine 2010, 29, 212-220.

34. Hsu, K.F.; Hung, C.F.; Cheng, W.F.; He, L.; Slater, L.A.; Ling, M.; Wu, T.C. Enhancement of suicidal DNA vaccine potency by linking Mycobacterium tuberculosis heat shock protein 70 to an antigen. Gene Ther. 2001, 8, 376-383.

35. Cheng, W.F.; Hung, C.H.; Chai, C.Y.; Hsu, K.F.; He, L.; Ling, M.; Slater, L.A.; Roden, R.B.; $\mathrm{Wu}$, T.C. Enhancement of sindbis virus self-replicating RNA vaccine potency by linkage of herpes simplex virus type 1 VP22 protein to antigen. J. Virol. 2001, 75, 2368-2376.

36. Schlesinger, S.; Dubensky, T.W. Alphavirus vectors for gene expression and vaccines. Curr. Opin. Biotechnol. 1999, 10, 434-439.

37. Hariharan, M.J.; Driver, D.A.; Townsend, K.; Brumm, D.; Polo, J.M.; Belli, B.A.; Catton, D.J.; Hsu, D.; Mittelstaedt, D.; McCormack, J.E.; et al. DNA immunization against herpes simplex virus: enhanced efficacy using a Sindbis virus-based vector. J. Virol. 1998, 72, 950-958.

38. Phenix, K.V.; Wark, K.; Luke, C.J.; Skinner, M.A.; Smyth, J.A.; Mawhinney, K.A.; Todd, D. Recombinant Semliki Forest virus vector exhibits potential for avian virus vaccine development. Vaccine 2001, 19, 3116-3123.

39. Zhou, X.; Berglund, P.; Rhodes, G.; Parker, S.E.; Jondal, M.; Liljestrom, P. Self-replicating Semliki Forest virus RNA as recombinant vaccine. Vaccine 1994, 12, 1510-1514.

40. Wolf, A.; Hodneland, K.; Frost, P.; Braaen, S.; Rimstad, E. A hemagglutinin-esterase-expressing salmonid alphavirus replicon protects Atlantic salmon (Salmo salar) against infectious salmon anemia (ISA). Vaccine 2013, 31, 661-669.

41. Pugachev, K.V.; Mason, P.W.; Shope, R.E.; Frey, T.K. Double-subgenomic Sindbis virus recombinants expressing immunogenic proteins of Japanese encephalitis virus induce significant protection in mice against lethal JEV infection. Virology 1995, 212, 587-594.

42. Pushko, P.; Parker, M.; Ludwig, G.V.; Davis, N.L.; Johnston, R.E.; Smith, J.F. Replicon-helper systems from attenuated Venezuelan equine encephalitis virus: Expression of heterologous genes in vitro and immunization against heterologous pathogens in vivo. Virology 1997, 239, 389-401.

43. Fleeton, M.N.; Liljeström, P.; Sheahan, B.J.; Atkins, G.J. Recombinant Semliki Forest virus particles expressing louping ill virus antigens induce a better protective response than plasmidbased DNA vaccines or an inactivated whole particle vaccine. J. Gen. Virol. 2000, 81, 749-758.

44. Morris-Downes, M.M.; Phenix, K.V.; Smyth, J.; Sheahan, B.J.; Lileqvist, S.; Mooney, D.A.; Liljestrom, P.; Todd, D.; Atkins, G.J. Semliki Forest virus-based vaccines: Persistence, distribution and pathological analysis in two animal systems. Vaccine 2001, 19, 1978-1988. 
45. Hevey, M.; Negley, D.; VanderZanden, L.; Tammariello, R.F.; Geisbert, J.;Smalljohn, C.; Smith, J.F.; Jahrling, P.B.; Smalljohn, A.L. Marburg virus vaccines: Comparing classical and new approaches. Vaccine 2001, 20, 586-593.

46. Hevey, M.; Negley, D.; Pushko, P.; Smith, J.; Schmaljohn, A. Marburg virus vaccines based upon alphavirus replicons protect guinea pigs and nonhuman primates. Virology 1998, 251, 28-37.

47. Pasetti, M.F.; Ramirez, K.; Resendiz-Albor, A.; Ulmer, J.; Barry, E.M.; Levine, M.M. Sindbis virus-based measles DNA vaccines protect cotton rats against respiratory measles: Relevance of antibodies, mucosal and systemic antibody-secreting cells, memory B cells, and Th1-type cytokines as correlates of immunity. J. Virol. 2009, 83, 2789-2794.

48. Pan, C.H.; Greer, C.E.; Hauer, D.; Legg, H.S.; Lee, E.Y.; Bergen, M.J.; Lau, B.; Adams, R.J.; Polo, J.M.; Griffin, D.E. A chimeric alphavirus replicon particle vaccine expressing the hemagglutinin and fusion proteins protects juvenile and infant rhesus macaques from measles. J. Virol. 2010, 84, 3798-3807.

49. Colombage, G.; Hall, R.; Pavy, M.; Lobigs, M. DNA-based and alphavirus-vectored immunisation with prM and $\mathrm{E}$ proteins elicits long-lived and protective immunity against the flavivirus, Murray Valley encephalitis virus. Virology 1998, 250, 151-163.

50. Harrington, P.R.; Yount, B.; Johnston, R.E.; Davis, N.; Moe, C.; Baris, R.S. Systemic, mucosal, and heterotypic immune induction in mice inoculated with Venezuelan equine encephalitis replicons expressing Norwalk virus-like particles. J. Virol. 2002, 76, 730-742.

51. Saxena, S.; Dahiya, S.S.; Sonwane, A.A.; Patel, C.L.; Saini, M.; Rai, A.; Gupta, P.K. A sindbis virus replicon-based DNA vaccine encoding the rabies virus glycoprotein elicits immune responses and complete protection in mice from lethal challenge. Vaccine 2008, 26, 6592-6601.

52. Fleeton, M.N.; Chen, M.; Berglund, P.; Rhodes, G.; Parker, S.E.; Murphy,M.; Atkins, G.J.; Liljestrom, P. Self-replicative RNA vaccines elicit protection against influenza A virus, respiratory syncytial virus, and a tickborne encephalitis virus. J. Infect. Dis. 2001, 183, 1395-1398.

53. Chen, M.; Hu, K.F.; Rozell, B.; Orvell, C.; Morein, B.; Liljestrom, P. Vaccination with recombinant alphavirus or immune-stimulating complex antigen against respiratory syncytial virus. J. Immunol. 2002, 169, 3208-3216.

54. Bhardwaj, N.; Heise, M.T.; Ross, T.M. Vaccination with DNA plasmids expressing Gn coupled to $\mathrm{C} 3 \mathrm{~d}$ or alphavirus replicons expressing gn protects mice against Rift Valley fever virus. PLoS Negl. Trop. Dis. 2010, 4, e725.

55. Sheahan, T.; Whitmore, A.; Long, K.; Ferris, M.; Rockx, B.; Funkhouser, W.; Donaldson, E.; Gralinski, L., Collier, M.; Heise, M.; et al. Successful vaccination strategies that protect aged mice from lethal challenge from influenza virus and heterologous severe acute respiratory syndrome coronavirus. J. Virol. 2011, 85, 217-230.

56. Kamrud, K.I.; Hooper, J.W.; Elgh, F.; Schmaljohn, C.S. Comparison of the protective efficacy of naked DNA, DNA-based Sindbis replicon, and packaged Sindbis replicon vectors expressing Hantavirus structural genes in hamsters. Virology 1999, 263, 209-219. 
57. Berglund, P.; Quesada-Rolander, M.; Putkonen, P.; Biberfeld, G.; Thorstensson, R.; Liljestrom, P. Outcome of immunization of cynomolgus monkeys with recombinant Semliki Forest virus encoding human immunodeficiency virus type 1 envelope protein and challenge with a high dose of SHIV-4 virus. AIDS Res. Hum. Retroviruses 1997, 13, 1487-1495.

58. Herbert, A.S.; Kuehne, A.I.; Barth, J.F.; Ortiz, R.A.; Nichols, D.K.; Zak, S.E.; Stonier, S.W.; Muhammad, M.A.; Bakken, R.R.; Prugar, L.I.; et al. Venezuelan equine encephalitis virus replicon particle vaccine protects nonhuman primates from intramuscular and aerosol challenge with ebolavirus. J. Virol. 2013, 87, 4952-4964.

59. Hooper, J.W.; Ferro, A.M.; Golden, J.W.; Silvera, P.; Dudek, J.; Alterson, K.; Custer, M.; Rivers, B.; Morris, J.; Owens, G.; et al. Molecular smallpox vaccine delivered by alphavirus replicons elicits protective immunity in mice and non-human primates. Vaccine 2009, 28, 494-511.

60. Yang, S.G.; Wo, J.E.; Li, M.W.; Mi, F.F.; Yu, C.B.; Lv, G.L.; Cao, H.C.; Lu, H.F.; Wang, B.H.; Zhu, H.; et al. Construction and cellular immune response induction of HA-based alphavirus replicon vaccines against human-avian influenza (H5N1). Vaccine 2009, 27, 7451-7458.

61. Xu, R.; Srivastava, I.K.; Greer, C.E.; Zarkikh, I.; Kraft, Z.; Kuller, L.; Polo, J.M.; Barnett, S.W.; Stamatatos, L. Characterization of immune responses elicited in macaques immunized sequentially with chimeric VEE/SIN alphavirus replicon particles expressing SIVGag and/or HIVEnv and with recombinant HIVgp140Env protein. AIDS Res. Hum. Retroviruses 2006, 22, 1022-1030.

62. Barnett, S.W.; Burke, B.; Sun, Y.; Kan, E.; Legg, H.; Lian, Y.; Bost, K.; Zhou, F.; Goodsell, A.; Zur Megede, J.; et al. Antibody-mediated protection against mucosal simian-human immunodeficiency virus challenge of macaques immunized with alphavirus replicon particles and boosted with trimeric envelope glycoprotein in MF59 adjuvant. J. Virol. 2010, 84, 5975-585.

63. Wu, Q.; Xu, F.; Fang, L.; Xu, J.; Li, B.; Jiang, Y.; Chen, H.; Xiao, S. Enhanced immunogenicity induced by an alphavirus replicon-based pseudotyped baculovirus vaccine against porcine reproductive and respiratory syndrome virus. J. Virol. Methods 2013, 187, 251-258.

64. Wolf, A.; Hodneland, K.; Frost, P.; Hoeijmakers, M.; Rimstad, E. Salmonid alphavirus-based replicon vaccine against infectious salmon anemia (ISA): Impact on infectious route and interactions of the replicon vector. Fish Shellfish Immunol. 2014, 36, 383-392.

65. Xu, C.; Mutoloki, S.; Evensen, O. Superior protection against conferred by inactivated whole virus vaccine over subunit and DNA vaccines against salmonid alphavirus infection in Atlantic salmon (Salmon salar L). Vaccine 2012, 30, 3918-3928.

66. Andersson, C.; Vasconcelos, N.M.; Sievertzon, M.; Haddad, D.; Liljeqvist, S. Comparative immunization study using RNA and DNA constructs encoding a part of the Plasmodium falciparum antigen Pf332. Scand. J. Immunol. 2001, 54, 117-124.

67. Kirman, J.R.; Turon, T.; Su, H.; Li, A.; Kraus, C.; Polo, J.M.; Belisle, J.; Morris, S.; Seder, R.A. Enhanced immunogenicity to Mycobacterium tuberculosis by vaccination with an alphavirus plasmid replicon expressing antigen 85A. Infect. Immun. 2003, 71, 575-579.

68. Li, N.; Yu, Y.Z.; Yu, W.Y.; Sun, Z.W. Enhancement of the immunogenicity of DNA replicon vaccine of Clostridium botulinum neurotoxin serotype A by GM-CSF gene adjuvant. Immunopharmacol. Immunotoxicol. 2011, 33, 211-219. 
69. Cabrera, A.; Sáez, D.; Céspedes, S.; Andrews, E.; Oñate, A. Vaccination with recombinant Semliki Forest virus particles expressing translation initiation factor 3 of Brucella abortus induces protective immunity in BALB/c mice. Immunobiology 2009, 214, 467-474.

70. Thomas, J.M.; Moen, S.T.; Gnade, B.T.; Vargas-Inchaustegui, D.A.; Foltz, S.M.; Suarez, G.; Heidner, H.W.; König, R.; Chopra, A.K.; Peterson, J.W. Recombinant Sindbis virus vectors designed to express protective antigen of Bacillus anthracis protect animals from anthrax and display synergy with ciprofloxacin. Clin. Vaccine Immunol. 2009, 16, 1696-1699.

71. Tsuji, M.; Bergmann, C.C.; Takita-Sonoda, Y.; Murata, K.; Rodrigues, E.G.; Nussenzweig, R.S.; Zavala, F. Recombinant Sindbis viruses expressing a cytotoxic T-lymphocyte epitope of a malaria parasite or of influenza virus elicit protection against the corresponding pathogen in mice. J. Virol. 1998, 72, 6907-6910.

72. Krasemann, S.; Jürgens, T.; Bodemer, W. Generation of monoclonal antibodies against prion proteins with an unconventional nucleic acid-based immunization strategy. J. Biotechnol. 1999, 73, 119-129.

73. Lee, J.S.; Dyas, B.K.; Nystrom, S.S.; Lind, C.M.; Smith, J.F.; Ullrich, R.G. Immune protection against staphylococcal enterotoxin-induced toxic shock by vaccination with a Venezuelan equine encephalitis virus replicon. J. Infect. Dis. 2002, 185, 1192-1196.

74. Ying, H.; Zaks, T.Z.; Wang, R.F.; Irvine, K.R.; Kammula, U.S.; Marincola, F.M.; Leitner, W.W.; Restifo, N.P. Cancer therapy using a self-replicating RNA vaccine. Nat. Med. 1999, 5, 823-827.

75. Leitner, W.W.; Hwang, L.N.; deVeer, M.J.; Zhou, A.; Silverman, R.H.; Williams, B.R.; Dubensky, T.B.; Ying, H.; Restifo, N.P. Alphavirus-based DNA vaccine breaks immunological tolerance by activating innate antiviral pathways. Nat. Med. 2003, 9, 33-39.

76. Avogadri, F.; Merghoub, T.; Maughan, M.F.; Hirschhorn-Cymerman, D.; Morris, J.; Ritter, E.; Olmsted, R.; Houghton, A.N.; Wolchok, J.D. Alphavirus replicon particles expressing TRP-2 provide potent therapeutic effect on melanoma through activation of humoral and cellular immunity. PLoS One 2010, 5, e12670.

77. Yamanaka, R.; Zullo, S.A.; Ramsey, J.; Yajima, N.; Tsuchiya, N.; Tanaka, R.; Blaese, M.; Xanthopoulos, K.G. Marked enhancement of antitumor immune responses in mouse brain tumor models by genetically modified dendritic cells producing Semliki Forest virus-mediated interleukin-12. J. Neurosurg. 2002, 97, 611-618.

78. Yamanaka, R.; Zullo, S.A.; Ramsey, J.; Onodera, M.; Tanaka, R.; Blaese, M.; Xanthopoulos, K.G. Induction of therapeutic antitumor antiangiogenesis by intratumoral injection of genetically engineered endostatin-producing Semliki Forest virus. Cancer Gene Ther. 2001, 8, 796-802.

79. Yamanaka, R.; Zullo, S.A.; Tanaka, R.; Blaese, M.; Xanthopoulos, K.G. Enhancement of antitumor immune response in glioma models in mice by genetically modified dendritic cells pulsed with Semliki forest virus-mediated complementary DNA. J. Neurosurg. 2001, 94, 474-481.

80. Yamanaka, R.; Xanthopoulos, K.G. Induction of antigen-specific immune responses against malignant brain tumors by intramuscular injection of sindbis DNA encoding gp100 and IL-18. DNA Cell Biol. 2005, 24, 317-324. 
81. Lachman, L.B.; Rao, X.M.; Kremer, R.H.; Ozpolat, B.; Kiriakova, G.; Price, J.E. DNA vaccination against neu reduces breast cancer incidence and metastasis in mice. Cancer Gene Ther. 2001, 8, 259-268.

82. Wang, X.; Wang, J.P.; Rao, X.M.; Price, J.E.; Zhou, H.S.; Lachman, L.B. Prime-boost vaccination with plasmid and adenovirus gene vaccines control HER2/neu+ metastatic breast cancer in mice. Breast Cancer Res. 2005, 7, R580-R588.

83. Eralp, Y.; Wang, X.; Wang, J.P.; Maughan, M.F.; Polo, J.M.; Lachman, L.B. Doxorubicin and paclitaxel enhance the antitumor efficacy of vaccines directed against HER 2/neu in a murine mammary carcinoma model. Breast Cancer Res. 2004, 6, R275-R283.

84. Laust, A.K.; Sur, B.W.; Wang, K.; Hubby, B.; Smith, J.F.; Nelson, E.L. VRP immunotherapy targeting neu: Treatment efficacy and evidence for immunoediting in a stringent rat mammary tumor model. Breast Cancer Res. Treat. 2007, 106, 371-382.

85. Moran, T.P.; Burgents, J.E.; Long, B.; Ferrer, I.; Jaffee, E.M.; Tisch, R.M.; Johnston, R.E.; Serody, J.S. Alphaviral vector-transduced dendritic cells are successful therapeutic vaccines against neu-overexpressing tumors in wild-type mice. Vaccine 2007, 25, 6604-6612.

86. Daemen, T.; Regts, J.; Holtrop, M.; Wilschut, J. Immunization strategy against cervical cancer involving an alphavirus vector expressing high levels of a stable fusion protein of human papillomavirus 16 E6 and E7. Gene Ther. 2002, 9, 85-94.

87. Daemen, T.; Riezebos-Brilman, A.; Regts, J.; Dontje, B.; van der Zee, A.; Wilschut, J. Superior therapeutic efficacy of alphavirus-mediated immunization against human papilloma virus type 16 antigens in a murine tumour model: Effects of the route of immunization. Antivir. Ther. 2004, 9 , 733-742.

88. Cheng, W.F.; Lee, C.N.; Su, Y.N.; Chai, C.Y.; Chang, M.C.; Polo, J.M.; Hung, C.F.; Wu, T.C.; Hsieh, C.Y.; Chen, C.A. Sindbis virus replicon particles encoding calreticulin linked to a tumor antigen generate long-term tumor-specific immunity. Cancer Gene Ther. 2006, 13, 873-885.

89. Velders, M.P.; McElhiney, S.; Cassetti, M.C.; Eiben, G.L.; Higgins, T.; Kovacs, G.R.; Elmishad, A.G.; Kast, W.M.; Smith, L.R. Eradication of established tumors by vaccination with Venezuelan equine encephalitis virus replicon particles delivering human papillomavirus 16 E7 RNA. Cancer Res. 2001, 61, 7861-7867.

90. Riezebos-Brilman, A.; Regts, J.; Chen, M.; Wilschut, J.; Daemen, T. Augmentation of alphavirus vector-induced human papilloma virus-specific immune and anti-tumour responses by coexpression of interleukin-12. Vaccine 2009, 27, 701-707.

91. Cheng, W.F.; Hung, C.F.; Hsu, K.F.; Chai, C.Y.; He, L.; Polo, J.M.; Slater, L.A.; Ling, M.; Wu, T.C. Cancer immunotherapy using Sindbis virus replicon particles encoding a VP22-antigen fusion. Hum. Gene Ther. 2002, 13, 553-568.

92. Smyth, J.W.; Fleeton, M.N.; Sheahan, B.J.; Atkins, G.J. Treatment of rapidly growing K-BALB and CT26 mouse tumours using Semliki Forest virus and its derived vector. Gene Ther. 2005, 12, $147-159$.

93. Lyons, J.A.; Sheahan, B.J.; Galbraith, S.E.; Mehra, R.; Atkins, G.J.; Fleeton, M.N. Inhibition of angiogenesis by a Semliki Forest virus vector expressing VEGFR-2 reduces tumour growth and metastasis in mice. Gene Ther. 2007, 14, 503-513. 
94. Yamanaka, R.; Zullo, S.A.; Tanaka, R.; Ramsey, J.; Blaese, M.; Xanthopoulos, K.G. Induction of a therapeutic antitumor immunological response by intratumoral injection of genetically engineered Semliki Forest virus to produce interleukin-12. Neurosurg. Focus 2000, 9, e7.

95. Lundstrom, K. Biology and application of alphaviruses in gene therapy. Gene Ther. 2005, 12, S92-S97.

96. Quetglas, J.I.; Dubrot, J.; Bezunartea, J.; Sanmamed, M.F.; Hervas-Stubbs, S.; Smerdou, C.; Melero, I. Immunotherapeutic synergy between anti-CD137 mAb and intratumoral administration of a cytopathic Semliki Forest virus encoding IL-12. Mol. Ther. 2012, 20, 1664-1675

97. Leslie, M.C.; Zhao, Y.J.; Lachman, L.B.; Hwu, P.; Wu, G.J.; Bar-Eli, M. Immunization against MUC18/MCAM, a novel antigen that drives melanoma invasion and metastasis. Gene Ther. 2007, 14, 316-323.

98. Morse, M.A.; Hobeika, A.C.; Osada, T.; Berglund, P.; Hubby, B.; Negri, S.; Niedzwiecki, G.; Devi G.R.; Burnett, G.K.; Clay, T.M. An alphavirus vector overcomes the presence of neutralizing antibodies and elevated numbers of Tregs to induce immune responses in humans with advanced cancer. J. Clin. Invest. 2010, 120, 3234-3241.

99. Slovin, S.F.; Kehoe, M.; Durso, R.; Fernandez, C.; Olson, W.; Gao, J.P.; Israel, R.; Sher, H.I.; Morris, S. A phase I dose escalation trial of vaccine replicon particles (VRP) expressing prostatespecific membrane antigen (PSMA) in subjects with prostate cancer. Vaccine 2013, 31, 943-949.

100. Durso, R.J.; Andjelic, S.; Gardner, J.P.; Margitich, D.J.; Donovan, G.P.; Arrigale, R.R.; Wang, X.; Maughan, M.F.; Talarico, T.L.; Olmsted, R.A. A novel alphavirus vaccine encoding prostate-specific membrane antigen elicits potent cellular and humoral immune responses. Clin. Cancer Res. 2007, 13, 3999-4008.

101. Garcia-Hernandez, M.L.; Gray, A.; Hubby, B.; Kast, W.M. In vivo effects of vaccination with six-transmembrane epithelial antigen of the prostate: A candidate antigen for treating prostate cancer. Cancer Res. 2007, 67, 1344-1351.

102. Garcia-Hernandez, M.L.; Gray, A.; Hubby, B.; Klinger, O.J.; Kast, WM. Prostate stem cell antigen vaccination induces a long-term protective immune response against prostate cancer in the absence of autoimmunity. Cancer Res. 2008, 68, 861-869.

103. Colmenero, P.; Chen, M.; Castaños-Velez, E.; Liljeström, P.; Jondal, M. Immunotherapy with recombinant SFV-replicons expressing the P815A tumor antigen or IL-12 induces tumor regression. Int. J. Cancer 2002, 98, 554-560.

104. Ying, H.; Zeng, G.; Black, K.L. Innovative cancer vaccine strategies based on the identification of tumour-associated antigens. BioDrugs 2001, 15, 819-831.

105. Colmenero, P.; Liljeström, P.; Jondal, M. Induction of P815 tumor immunity by recombinant Semliki Forest virus expressing the P1A gene. Gene Ther. 1999, 6, 1728-1733.

106. Leitner, W.W.; Ying, H.; Driver, D.A.; Dubensky, T.W.; Restifo, N.P. Enhancement of tumorspecific immune response with plasmid DNA replicon vectors. Cancer Res. 2000, 60, 51-55.

107. Daemen, T.; Pries, F.; Bungener, L.; Kraak, M.; Regts, J.; Wilschut, J. Genetic immunization against cervical carcinoma: induction of cytotoxic $\mathrm{T}$ lymphocyte activity with a recombinant alphavirus vector expressing human papillomavirus type 16 E6 and E7. Gene Ther. 2000, 7, $1859-1866$. 
108. Cheng, W.F.; Hung, C.F.; Hsu, K.F.; Chai, C.Y.; He, L.; Ling, M.; Slater, L.A.; Roden, R.B.; $\mathrm{Wu}$, T.C. Enhancement of sindbis virus self-replicating RNA vaccine potency by targeting antigen to endosomal/lysosomal compartments. Hum. Gene Ther. 2001, 12, 235-252.

109. Eiben, G.L.; Velders, M.P.; Schreiber, H.; Cassetti, M.C.; Pullen, J.K.; Smith, L.R.; Kast, W.M. Establishment of an HLA-A*0201 human papillomavirus type 16 tumor model to determine the efficacy of vaccination strategies in HLA-A*0201 transgenic mice. Cancer Res. 2002, 62, 5792-5799.

110. Cassetti, M.C.; McElhiney, S.P.; Shahabi, V.; Pullen, J.K.; Le, Poole, I.; Eiben, G.L.; Smith, L.R.; Kast, W.M. Antitumor efficacy of Venezuelan equine encephalitis virus replicon particles encoding mutated HPV16 E6 and E7 genes. Vaccine 2004, 22, 520-527.

111. Yamanaka, R.; Tsuchiya, N.; Yajima, N.; Honma, J.; Hasegawa, H.; Tanaka, R.; Ramsey, J.; Blaese, R.M.; Xanthopoulos, K.G. Induction of an antitumor immunological response by an intratumoral injection of dendritic cells pulsed with genetically engineered Semliki Forest virus to produce interleukin-18 combined with the systemic administration of interleukin-12. J. Neurosurg. 2003, 99, 746-753.

112. Bennett, A.M.; Elvin, S.J.; Wright, A.J.; Jones, S.M.; Phillpotts, R.J. An immunological profile of Balb/c mice protected from airborne challenge following vaccination with a live attenuated Venezuelan equine encephalitis virus vaccine. Vaccine 2000, 19, 337-347.

113. Hart, M.K.; Caswell-Stephan, K.; Bakken, R.; Tammariello, R.; Pratt, W.; Davis, N.; Johnston, R.E.; Smith, J.; Steele, K. Improved mucosal protection against Venezuelan equine encephalitis virus is induced by the molecularly defined, live-attenuated V3526 vaccine candidate. Vaccine 2000, 18, 3067-3075.

114. Schoepp, R.J.; Smith, J.F.; Parker, M.D. Recombinant chimeric western and eastern equine encephalitis viruses as potential vaccine candidates. Virology 2002, 302, 299-309.

115. Edelman, R.; Tacket, C.O.; Wasserman, S.S.; Bodison, S.A.; Perry, J.G.; Mangiafico, J.A. Phase II safety and immunogenicity study of live chikungunya virus vaccine TSI-GSD-218. Am. J. Trop. Med. Hyg. 2000, 62, 681-685.

116. Mallilankaraman, K.; Shedlock, D.J.; Bao, H.; Kawalekar, O.U.; Fagone, P.; Ramanathan, A.A.; Ferraro, B. A DNA vaccine against chikungunya virus is protective in mice and induces neutralizing antibodies in mice and nonhuman primates. PLoS Negl. Trop. Dis. 2011, 5, e928.

117. Kim, D.Y.; Atasheva, S.; Foy, N.J.; Wang, E.; Frolova, E.I.; Weaver, S.; Frolov, I. Design of chimeric alphaviruses with a programmed, attenuated, cell type-restricted phenotype. J. Virol. 2011, 85, 4363-4376.

118. Kramer, R.M.; Zeng, Y.; Sahni, N.; Kueltzo, L.A.; Schwartz, R.M.; Srivastava, I.K.; Crane, L.; Joshi, S.B.; Volkin, D.B.; Middaugh, C.R. Development of a stable virus-like particle vaccine formulation against Chikungunya virus and investigation of the effects of polyanions. J. Pharm. Sci. 2013, 102, 4305-4314.

119. Dash, P.K.; Tiwari, M.; Santhosh, S.R.; Parida, M.; Lakshmana Rao, P.V. RNA interference mediated inhibition of Chikungunya virus replication in mammalian cells. Biochem. Biophys. Res. Commun. 2008, 376, 718-722. 
120. Kamrud, K.I.; Coffield, V.M.; Owens, G.; Goodman, C.; Alterson, K.; Custer, M.; Murphy, M.A.; Lewis, W.; Timberlake, S.; Wansley, E.K. In vitro and in vivo characterization of microRNAtargeted alphavirus replicon and helper RNAs. J. Virol. 2010, 84, 7713-7725.

121. Elvin, S.J.; Bennett, A.M.; Phillpotts, R.J. Role for mucosal immune responses and cell-mediated immune functions in protection from airborne challenge with Venezuelan equine encephalitis virus. J. Med. Virol. 2002, 67, 384-393.

122. Dupuy, L.C.; Richards, M.J.; Reed, D.S.; Schmaljohn, C.S. Immunogenicity and protective efficacy of a DNA vaccine against Venezuelan equine encephalitis virus aerosol challenge in nonhuman primates. Vaccine 2010, 28, 7345-7350.

123. Darwin, J.R.; Kenney, J.L.; Weaver, S.C. Transmission potential of two chimeric Chikungunya vaccine candidates in the urban mosquito vectors, Aedes aegypti and Ae. albopictus. Am. J. Trop. Med. Hyg. 2011, 84, 1012-1015.

124. Bhomia, M.; Sharma, A.; Gayen, M.; Gupta, P.; Maheshwari, R.K. Artificial microRNAs can effectively inhibit replication of Venezuelan equine encephalitis virus. Antivir. Res. 2013, 100, 429-434.

125. Prow, T.W.; Chen, X.; Prow, N.A.; Fernando, G.J.; Tan, C.S.; Raphael, A.P.; Chang, D.; Ruutu, M.D.; Jenkins, D.W.; Pyke, A. Nanopatch-targeted skin vaccination against West Nile Virus and Chikungunya virus in mice. Small 2010, 6, 1776-1784.

126. Berglund, P.; Sjöberg, M.; Garoff, H.; Atkins, G.J.; Sheahan, B.J.; Liljestrom, P. Semliki Forest virus expression system: Production of conditionally infectious recombinant particles. Biotechnology 1993, 11, 916-920..

(C) 2014 by the authors; licensee MDPI, Basel, Switzerland. This article is an open access article distributed under the terms and conditions of the Creative Commons Attribution license (http://creativecommons.org/licenses/by/3.0/). 